\title{
The Effects of Plyometric Training and Age on The Agility of Silat Fighters
}

\author{
Rodhi R. Hidayat \\ Sport Science Faculty \\ Cenderawasih University \\ Papua, Indonesia \\ hidayatrod@gmail.com
}

\author{
Tomoliyus \\ Sport Science Faculty \\ Yogyakarta State University \\ Yogyakarta, Indonesia \\ tomoliyus@uny.ac.id
}

\begin{abstract}
This research purpose to compare the effects of plyometric training on the agility of fighters in the age of 12-14 and 14-17 years old. Agility is an essential component in martial arts as it becomes a measure of the quality of martial arts performance. This research is experimental research. The data collection technique was using Hexagonal Obstacle Test. Sixteen subjects in the age of 12-17 years old were randomly assigned. The data analysis technique used two-way ANOVA at significance level 0.05 . The analysis results show that the average difference of pretest and posttest of eight-weeksplyometric exercise has an average improvement of $12,82 \%$ on age of $12-14$ and $14,56 \%$ on age of $14-17$ years old. Meanwhile, six-weeks-plyometric exercise has an average growth of $12,57 \%$ on age of $12-14$ and $13,46 \%$ on age of 14-17 years old. The conclusion of this research proves that there is an influence of 6 weeks and 8 weeks of agility training of 12-14 and 14-17 years old fighters, and there is a difference of plyometric effect of 6 weeks and 8 weeks on agility and there is a difference of influence of plyometric training for fighters in the age of 12-14 and 14-17 years old.
\end{abstract}

\section{Keywords_plyometric, age, agility}

\section{INTRODUCTION}

Some preparations to do in order to achieve athlete's maximum achievement are physical, technical, tactical, psychological, and theoretical training [1]. Physical skill is a foundation to enhance all factors in training [1]. If the physical foundation is stronger, then the potency to enhance technical, tactical, and psychological factor is bigger [1]. An appropriate physical skill would support technical and tactical performance during training and competition [1]. The athlete's ability to perform on high level is affected by his ability to perform strength, speed, and endurance which is usually called biomotor [2]. The biomotor composition of strength, speed, and endurance in some sports are formed differently [2]. Biomotor is also an important aspect to achieve maximum achievement, especially in the step of training preparation program. Therefore, every sport has their own physiological and specific characteristics based on the body energy system and the application of that particular sport's movement [2].

The biomotor components which are required in pencak silat are strength, speed, power, flexibility, coordination, and agility [3]. Among those biomotor components, agility is the most dominant biomotor component. Pencak silat competition is usually held in a small area and it demands the silat fighter in fighting category to keep moving in order to attack, avoid, parry, and other rhythmic movements before the silat fighters start to fight. The component of agility biomotor is very important in pencak silat because it helps the silat fighters react, do explosive movements, slow the movement down, build an attack in the form of kicking, hitting, slamming, and breaking the opponent's stance [3]. Agility could help the silat fighters do the right action from every position because the silat fighters has to always react and change his position based on the opponent's actions [3]. Thus, it is important for silat fighters to enhance his ability in order to increase the body awareness which support him in one-on-one fight and minimize the risk of getting injury [3].

One of exercise programs to train and improve agility is plyometric method. Plyometric was firstly introduced to Russian athletes to help them improve their speed and strength through jumping technique [4]. Previous literatures prove that plyometric is more effective to improve speed and strength than weight exercise [4]. Plyometric's work in improving speed and strength happens during eccentric and concentric cycle when the potential energy of muscle is saved and utilized [4]. Potential energy is saved during eccentric phase of muscle's action then it is used or utilized during concentric phase [4]. In order to reform muscle potential energy in eccentric and concentric cycle, every eccentric action must be followed by concentric action immediately [4]. Plyometric exercise program in this research tries to help athletes improve their physical ability in speed and strength so that they can move faster and more agile [4].

The basic component to form agility is the combination on speed, coordination, and flexibility [2]. The role of plyometric in this research is to help improve agility component through increasing speed [4]. Since the combination of strength and speed results in power, plyometric indirectly gives effect on the improvement of agility [4].

\section{LITERATURE REVIEW}

\section{A. Agility in Silat Fight}

Agility is a fitness component which is needed a lot in the most of sport activities [5], [6]. Agility is known as a 
capability to change direction, start, and stop motion quickly [7], [8], [9], [10]. Agility is defined as a fast movement of the whole body with a changing of speed and/or direction as a response to a stimulus with power, cognitive process, and skill techniques [11], [12].

In pencak silat competition, agility component has a big role since the silat fighters fight in a circle arena of $8 \mathrm{~m}^{2}$. Silat fighters in fighting category are supposed to be able to move quickly to change direction or vary the movements' pattern. Movement techniques which are used in the game are basically useful to anticipate, avoid, and attack the opponent by using agile movements [13]. Speed and agility are needed the most in martial arts [14]. The movement characteristics in fighting category of pencak silat need hopping and fast jumping to every direction [11]. The agility of martial arts shows the performance quality of the silat fighters [15], [3]. In order to achieve the motion characteristic in pencak silat, agility is the important factor that needs to be improved to add the aggressiveness of attacking, avoiding, and defending [3]. A silat fighter with a good agility will be able to control the centre point of his body weight when it turns into a movement and more effective and efficient power [8], [6].

The role of agility is the determiner of direction and speed change quickly as response to a stimulus [8]. Agility is formed by subcomponents which consist of physical quality and cognitive ability [8]. Based on physical quality, the constituents of agility are speed, strength, power, technique, and the quality of foot muscle [8]. The combination of speed, coordination, flexibility, and strength results in agility [2]. It needs to be paid attention that agility needs push from power where behind power there is maximum strength [2]. The last support of agility which is very influential is flexibility. It is directly connected to the range of joints' movements which is important to prevent injury and Silat fighters in fighting category who want to achieve better agility should fix maximum strength, maximum speed, and foot muscles endurance [14]. Some parts of foot muscles that need to be trained are musculas gastrocnemius, musculas soleus, dan musculas tibialis anterior and the collection of muscles in the front thighs. Every action that needs agility component must depend on foot strength. Agility component is continuously needed by silat fighters in fighting category when they are in defensive mode. Agility is ideally given when the athletes are in a special training schedule from a whole year training program [2]. Based on the literatures, the suggested periodization of agility training is three weeks, six weeks, or four until five weeks before competition, but it also depends on the trainer if he wants to run the preparation of special exercise program more than six [14].

\section{B. Age in Silat Fight}

The age to join pencak silat starts from 10 years old category, then followed by 12-14 years old, 14-17 years old, 17-35 years old, and above 35 years old or master category [16]. Based on the multilateral principal, children in the age of 11-14 years old need improvements in flexibility, coordination, balance, and agility through common power exercise which involves weight, increases moderate intensity of aerobic and anaerobic capacity, and gives opportunities in real situation of competition in a fun way [14]. Referring to the achievement of pencak silat movement characteristic which is agility, children in 12-14 and 14-17 years old category need agility exercise programs with adjustment in the volume and intensity of exercise based on the age category [14].

\section{Plyometric}

Plyometric training is not designed to be a program which could stand by itself [17]. Plyometric exercise is designed to improve strength of particular muscle [7]. Therefore, plyometric exercise needs to be integrated in other supporting exercise programmes so that it has exercise variation [7]. The key of safe and effective plyometric program is based on the developing age and level of fitness [7].

The basic principle of plyometric exercise is called P.R.O.S., which is an acronym of Progress, Recovery, Overload, and Specificity [7]. Based on the plyometric exercise concept, intensity of plyometric exercise is differentiated into two categories [9]. The first category is based on the number of foot contact to floor. It is mentioned that more than 200 foot contact is high intensity and 400 foot contact is low intensity in a training session [9]. The second category is based on the joints' absorbance during plyometric exercise [22].

Another source mentions that the concept of plyometric training program is divided into three ranks based on the volume and intensity [7]. The plyometric exercise program has low, middle, and high [7]. The low plyometric exercise prepares muscles and basic skills, namely power, strength, muscle endurance, and balance to turn into better and more complex skills [7]. The middle plyometric exercise aims to give stimulus in order to improve fitness' components [7]. The high plyometric exercise aims to shape specific skills based on the particular sport. This plyometric training program is a conditioning method intensely. It is better for young silat fighters to start the training with low intensity then improve it later [24].

\section{MATERIAL AND METHODOLOGY}

\section{A. Participats}

This research used experimental research with factorial design $2 \times 2$ [13]. The research population was 62 young male silat fighters Through purposive sampling, 16 samples were obtained based on some criteria, i.e. in the age of 12-17 years old, healthy, and had been trained in pencak silat for a year and above. The free variable of this study was the plyometric exercise method. Meanwhile, the dependent variable of this study was the agility of male silat fighters in fighting category. Lastly, the attributive variable in this research was the age variations which are 12-14 and 14-17 years old.

\section{B. Measurement}

The data collection technique was a measurement using Mackenzie' Hexagonal Obstacle Test. The validity point of Hexagonal Obstacle Test is 0,165 [18]. The data analysis was using ANOVA two-way in significance $\alpha=0,05$. 


\section{Procedure}

The plyometric exercise period consisted of six weeks and eight weeks for each group in the age of 12-14 years old and 14-17 years old. Based on the exercise period, plyometric exercise program in this research includes in special preparation period with macro cycle of 1.5-2 months and micro cycle of 6-8 weeks [6]. The special characteristic of special preparation is in the end of period, the volume will decrease and the intensity will increase [6]. The exercise frequency was twice a week. The exercise was done in the afternoon. The exercise unit includes warming up, evaluation, and cooling down. The purpose of six weeks and eight weeks of plyometric exercise toward groups in the age of 12-14 and 14-17 years old in special training step was to improve physical condition to be more specific in accordance to the specific sport [1]. Based on the newest concept of plyometric, the exercise intensity is high because there were more than 200 foot works in every meeting [8]. Meanwhile based on the intensity level of joints absorbance towards power, this exercise program was considered low [19].

TABLE I. DESIGN OF PlyOMETRIC EXERCISE PROGRAM

\begin{tabular}{|c|c|c|}
\hline \multirow{2}{*}{$\begin{array}{c}\text { Exercise } \\
\text { Component }\end{array}$} & \multicolumn{2}{|c|}{ Age } \\
\hline & 12-14 years old & 14-17 years old \\
\hline Period & Special Preparation & Special Preparation \\
\hline Intensity & low, moderate, high & low, moderate, high \\
\hline Volume & $104-120$ foot contact & $144-198$ foot contact \\
\hline Recovery & $1: 4$ & $1: 4$ \\
\hline T. Interval & $1: 8$ & $1: 8$ \\
\hline Exercise Goal & $\begin{array}{l}\text { To improve: strength, } \\
\text { speed }\end{array}$ & $\begin{array}{l}\text { To improve: strength, } \\
\text { speed }\end{array}$ \\
\hline $\begin{array}{l}\text { Exercise } \\
\text { Period }\end{array}$ & $\begin{array}{l}6 \text { weeks }(12 x \text { exercise }) \\
8 \text { weeks ( } 16 x \text { exercise })\end{array}$ & $\begin{array}{l}6 \text { weeks ( } 12 x \text { exercise }) \\
8 \text { weeks ( } 16 x \text { exercise })\end{array}$ \\
\hline Days & Tuesday and Thursday & Wednesday and Friday \\
\hline Duration & 45 minutes & 45 minutes \\
\hline Rhythm & As fast as possible & As fast as possible \\
\hline Frecuency & Twice a week & Twice a week \\
\hline Break & 2-3 minutes between set & 2-3 minutes between set \\
\hline Weight & Low / their own weight & Low / their own weight \\
\hline
\end{tabular}

The data collection of pre-test was acquired by doing agility test with Hexagonal Obstacle Test. The research was conducted in Padepokan Pencak Silat Persinas ASAD Klaten, Jl. Mayor Sunaryo, Klaten Utara, Klaten, Central Java. The researcher divided the age and the plyometric exercise period into two categories, so that there were four groups of participants. The researchers held pre-test of participants' agility skill toward dependent variable and recorded the result of pre-test. Then, the researchers put those four groups in six weeks and eight weeks of plyometric exercise period. The silat fighters of fighting category in the age of 12-14 years old did plyometric exercise program on Tuesday and Thursday, while the silat fighters of fighting category in the age of 14-17 years old did plyometric exercise program on Wednesday and Friday.

\section{RESULT AND DISCUSSION}

\section{A. Result}

The data collection of pre-test was done on Friday, February 52016 at $7.30-9$ p.m., meanwhile the data collection of post-test was done on Monday, February 17 2018 at 3.30-5.30 p.m. The treatment was conducted in 12 and 16 meetings with the frequency of twice a week, every Wednesday and Friday. Age, plyometric training period, and the agility of silat fighters in fighting category are stated as mean. Normal distribution and homogeneity of all data was analysed using Kolmogorov Smirnov's normality test technique and Levene test. Two-way ANAVA analysis in significant level $\alpha=0,05$ was used to test the effect of age and plyometric training period variables toward silat fighters' ability and reveal the result between age and plyometric training period variables toward the agility of silat fighters in fighting category.

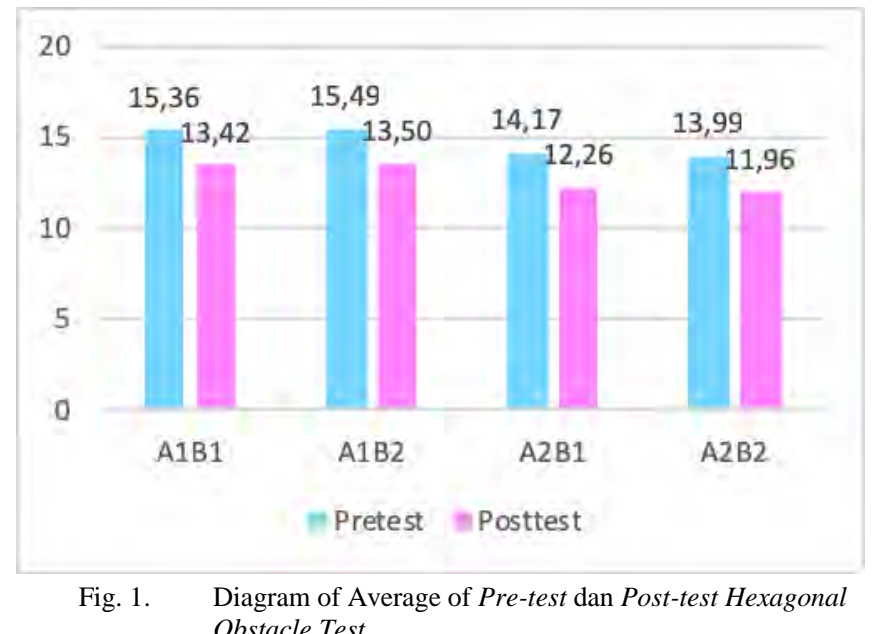

A1B1: Group of pre-teenager male silat fighters in fighting category with six weeks of plyometric exercise

A2B1: Group of pre-teenager male silat fighters in fighting category with eight weeks of plyometric exercise

A1B2: Group of teenager male silat fighters in fighting category with six weeks of plyometric exercise

A2B2: Group of teenager male silat fighters in fighting category with eight weeks of plyometric exercise

Diagram in figure 1 exhibits the achievement data of average agility in pre-test and post-test Hexagonal Obstacle Test of silat fighters in fighting category in the age of 12-14 and 14-17 years old with six weeks and eight weeks of plyometric exercise. The blue diagram shows the average of pre-test achievement, while the orange diagram reveals the average of post-test achievement. The orange diagram has lower score (in second) which shows the improvement in the achievement after the dependent variable got plyometric exercise.

Meanwhile, the results of the statistics counting of pretest and post-test Hexagonal Obstacle Test periodization 6 weeks and 8 weeks plyometric training in the Age of 12-14 and 14-17 years old could be seen below. 
TABLE II. THE STATISTICAL DESCRIPTION OF PRE-TEST AND POST-TEST ON THE SILAT FIGHTERS IN FIGHTING CATEGORY

\begin{tabular}{|c|c|c|c|c|c|}
\hline \multirow{2}{*}{ Age } & \multirow{2}{*}{ Period } & \multirow{2}{*}{ Statistics } & \multirow{2}{*}{$\mathbf{N}$} & \multicolumn{2}{|c|}{ Result of Agility Test } \\
\hline & & & & Pre-test & Post-test \\
\hline \multirow{6}{*}{$\begin{array}{l}\text { Pre-teenagers } \\
\text { (A1) }\end{array}$} & \multirow{3}{*}{$\begin{array}{l}6 \text { Weeks } \\
\text { (B1) }\end{array}$} & Total & \multirow{3}{*}{7} & 107.49 & 93.97 \\
\hline & & Avg & & 15.356 & 13.424 \\
\hline & & SD & & 0.719 & 0.483 \\
\hline & \multirow{3}{*}{$\begin{array}{l}8 \text { Weeks } \\
\text { (B2) }\end{array}$} & Total & \multirow{3}{*}{5} & 77.45 & 67.52 \\
\hline & & Avg & & 15.490 & 13.504 \\
\hline & & SD & & 0.602 & 0.533 \\
\hline \multirow{6}{*}{$\begin{array}{l}\text { Teenagers } \\
\text { (A2) }\end{array}$} & \multirow{3}{*}{$\begin{array}{l}6 \text { Weeks } \\
\text { (B1) }\end{array}$} & Total & \multirow{3}{*}{6} & 85.03 & 73.58 \\
\hline & & Avg & & 14.172 & 12.263 \\
\hline & & SD & & 0.525 & 0.585 \\
\hline & \multirow{3}{*}{$\begin{array}{l}8 \text { Weeks } \\
\text { (B2) }\end{array}$} & Total & \multirow{3}{*}{5} & 69.97 & 59.78 \\
\hline & & Avg & & 13.994 & 11.956 \\
\hline & & SD & & 0.350 & 0.570 \\
\hline
\end{tabular}

Six weeks and eight weeks of plyometric training process toward the silat fighters in the age of 12-14 and 14-17 years old seem to give a benefit which is calculated in the table. The benefit of plyometric training is increasing the agility achievement which is measured by using hexagonal obstacle test. The result of agility test in post-test column is smaller than in pre-test column. The enhancement of the test result which was using hexagonal obstacle test uses time as a unit of measurement. It means the faster the time, the better achievement that the silat fighter gets at the moment.

Based on the statistical analysis of homogeneity test that had been done using Levene test, the pre-test phase has significant point of $0.222>0,05$. Meanwhile, the post-test phase has significant point of $0.072>0,05$. The pre-test and post-test score in data group shows homogeny variance.

\section{TABLE III. HomogeneIty Test USING LEVENE TEST}

\begin{tabular}{|c|r|r|r|r|c|}
\hline Group & $\begin{array}{c}\text { Levene } \\
\text { Statistic }\end{array}$ & df1 & df2 & Sig. & Description \\
\hline Pre-test & 1.601 & 3 & 19 & 0.222 & Homogeny \\
\hline Post-test & 2.731 & 3 & 19 & 0.072 & Homogeny \\
\hline
\end{tabular}

Based on the statistical analysis of normality test in all of pre-test and post-test data, the data of silat fighters' agility in Persinas ASAD, Klaten was distributed normally. The data normality from all of significant point is $\mathrm{p}>0.05$.

TABLE IV. NORMALITY TEST

\begin{tabular}{|c|c|c|c|}
\hline Data & $p$ & Significance & Description \\
\hline Pretest A1B1 & 0.992 & \multirow{8}{*}{0,05} & Normal \\
\hline Posttest A1B1 & 0.997 & & Normal \\
\hline Pretest A1B2 & 0.723 & & Normal \\
\hline Posttest A1B2 & 0.913 & & Normal \\
\hline Pretest A2B1 & 0.999 & & Normal \\
\hline Posttest A2B1 & 0.759 & & Normal \\
\hline Pretest A2B2 & 0.918 & & Normal \\
\hline Posttest A2B2 & 0.729 & & Normal \\
\hline
\end{tabular}

TABLE V. ANAVA TWO-WAY OF THE EFFECT OF PLYOMETRIC TRAINING METHOD (SIX WEEKS AND EIGHT WEEKS OF TRAINING PERIOD) AND THE AGE DIFFERENCE TOWARD THE SILAT FIGHTERS' AGILITY IN FIGHTING CATEGORY PERGURUAN PERSINAS ASAD.

\begin{tabular}{|l|l|l|l|l|l|}
\hline \multicolumn{7}{|c|}{ Tests of Between-Subjects Effects } \\
\hline Source & $\begin{array}{l}\text { Type III } \\
\text { Sum of } \\
\text { Squares }\end{array}$ & df & $\begin{array}{l}\text { Mean } \\
\text { Square }\end{array}$ & F & Sig. \\
\hline $\begin{array}{l}\text { Corrected } \\
\text { Model }\end{array}$ & $12.432^{\mathrm{a}}$ & 3 & 4.144 & 18.877 & 0 \\
\hline Intercept & 2615.044 & 1 & 2615.044 & 11911.718 & 0 \\
\hline AGE & 10.425 & 1 & 10.425 & 244.379 & 0.000 \\
\hline PERIOD & 14.036 & 1 & 14.036 & 329.012 & 0,000 \\
\hline Error & 2.634 & 12 & 0.22 & & \\
\hline Total & 2630.111 & 16 & & & \\
\hline $\begin{array}{l}\text { Corrected } \\
\text { Total }\end{array}$ & 15.067 & 15 & & & \\
\hline
\end{tabular}

R Squared $=.825$ (Adjusted R Squared $=.781$ )

Based on the table 5, Period is known that $F=329,012$, while significant point $p$ is 0,000 . Since the significant point $\mathrm{p}$ is $0,000<0,05$, Ho is denied. Thus, there is a different effect between six and eight weeks of plyometric training program of silat fighters in fighting category in Persinas ASAD, Klaten. Based on the analysis result, the average difference between pre-test and post-test of six weeks of plyometric training program is lower (pre-teenager $=1,93 \mathrm{~s}$, teenager $=$ $1,9 \mathrm{~s}$ ) than eight weeks of plyometric training program (preteenager $=1,98 \mathrm{~s}$, teenager $=2,03 \mathrm{~s}$ ). It means that the research hypothesis which states that there is a different effect between six and eight weeks of plyometric training program of silat fighters in fighting category in Persinas $A S A D$, Klaten has been proven.

The hypothesis test was conducted based on the analysis result and analysis interpretation of ANOVA two-way. There are effects between age toward agility of silat fighters in fighting category in Perguruan Persinas ASAD, Klaten. From the statistical calculation, it was obtained that $\mathrm{F}=$ 244.379, while significant point $\mathrm{p}=0,000$. Therefore, significant point $\mathrm{p} 0,000<0,05$ shows the different effect of plyometric training toward silat fighters in fighting category in the age of 12-14 and 14-17 years old. There are effects between six weeks and eight weeks of plyometric training toward agility of silat fighters in fighting category in Perguruan Persinas ASAD, Klaten. From the statistical calculation, it was obtained that $\mathrm{F}=329.012$, while significant point $\mathrm{p}=0,000$. If significant point $\mathrm{p} 0,000<$ 0,05 , there will be a different effect of six weeks and eight weeks of plyometric training toward the agility of silat fighters in fighting category in the age of 12-14 and 14-17 years old. Plyometric training program which were given to pre-teenager silat fighters (12-14 years old) could give more improvements in their agility than the agility of teenager silat fighters (14-17 years old) in Persinas ASAD, Klaten. Significant point of age factor $(0,000)<0,05$ shows the different effect between silat fighters' age and silat fighters' agility. 


\section{B. Discusion}

Based on the literatures, there are two statements about constituent components of agility. The first source states that agility is a combination of speed, flexibility, and coordination [2], [20]. The second source mentions that agility is the combination of speed, strength, power, and technique [10]. The purpose of agility exercise is to improve and turn speed and strength components into power [24], [4], [23], [10].

Based on the biomotor abilities table, agility is formed by speed, coordination and flexibility [2]. The theory that the researchers use is by improving speed through plyometric exercise, it would also improve agility [2]. Strength as the result of plyometric training would affect muscles quality in doing stronger movements to support speed component [8]. Strength is a determiner factor in agility because the improvement of strength helps move the body faster during position changing [8]. As a support of agility component, the form of plyometric exercise has coordination and flexibility aspects. From the researches about functional anatomy and supporting movements in special training program (agility), there is a role of musculoskeletal system mechanism which is improving a biomotor component would also improve other derived biomotors [8].

Even though it is plyometric training, there are flexibility and coordination aspects in it. The mechanism of agility formulation is begun by speed factor which is applied in order to get the intended position in a short time. It needs full control toward actions so that the movements are effective and efficient. It also needs support of wide and complex musculoskeletal movements' flexibility. In this research, agility is not a direct effect of plyometric exercise but it is the effect of speed (as the purpose of plyometric exercise) which affects agility since speed is a constituent of agility. The speed improvement would support fast movements in changing direction without losing balance.

The conclusion of this research proves that plyometric training does not improve agility directly because the purpose of plyometric is to improve strength and speed. However, plyometric could give effect to agility because the supporting biomotors of agility are speed, coordination, and flexibility. If plyometric is able to affect agility, then speed component (the result of plyometric and one of agility components) is the one which gives effect toward agility.

\section{ACKNOWLEDGMENT}

The researchers would like to say thank you to the silat fighters in fighting category in Perguruan Persinas ASAD, Klaten who were willingly participate in this research with high enthusiasm and to pencak silat trainers in Perguruan Persinas ASAD, Klaten who helped run six weeks and eight weeks of plyometric training program. And also the administration support from Postgraduate Program, Universitas Negeri Yogyakarta and facilities support for test measuring from Faculty of Sport Science, Universitas Negeri Yogyakarta.

\section{REFERENCES}

[1] T. O. Bompa, and H. Gregory, Periodization. (A. Ewing, Ed.) Illinois: Human Kinetics, 2009.

[2] T. Bompa, and C. Buzzichelli, Periodization Training for Sports. (L. Pulliam, Ed.), 3rd ed., Illinois, US: Human Kinetics, 2015.

[3] L. Landow, Ultimate Conditioning for Martial Arts. (C. McEntire, Ed.), 1st ed., Illinois, US: Human Kinetics, 2016.

[4] A. Chu, and G. Myer, PLYOMETRICS. (H. H. and C. McEntire, Ed.), 1st ed., London, UK: Human Kinetics, 2013.

[5] M. E. Marjani, and S. K. Geok, "Group Decision Making Approach in Karate Agility Test Selection,” In M. E. Marjani (Ed.), Proceedings of the International Symposium on the Analytic Hierarchy Process 2013 (pp. 1-11). Selangor: Department of Sports Studies University Putra Malaysia Selangor, Malaysia, 2013.

[6] Rameshkannan and B. Chittibabu, "Effect of Plyometric Training on Agility Performance of Male Handball Players", International Journal of Physical Education, Fitness and Sports, 3(4), pp. 72-76, 2014.

[7] B. S. Bal, P. J. Kaur, and D. Singh, "Effects of a Short Term Plyometric Training Program of Agility in Young Basketball", Brazilian Journal of Biomotricity, 5(4), pp. 271-278, 2011. Retrieved from http://www.brjb.com.br/files/brjb_163_5201112_id2.pdf

[8] Dawes, J., and Roozen, M., Developing Agility and Quickness. (J. Dawes, Ed., 1st ed., Illinois, US: Human Kinetics, 2012.

[9] C. S. Kumar, "Effect of land plyometric and sand plyometric training on selected physical and physiological variables among hockey players", International Journal of Physical Education, Sports and Health, 3(3), pp. 540-544, 2016.

[10] Meylan, C., "Effects of in-season plyometric training within soccer practice on explosive actions of young players", Journal of Strength and Conditioning Research, 23(9), pp. 2605-2613, 2009.

[11] Alexander, Chambers, and Draeger, Pentjak Silat 1st ed., Tokyo, Japan: Kodanshn International Ltd, 1970

[12] Villarreal, E., Requena, B., and Cronin, J. B., "The Effects of Plyometric Training on Change-of-Direction Ability", International Journal of Sports Physiology and Performance, 11(5), pp. 563-573, 2016. Retrieved https://doi.org/http://dx.doi.org/10.1123/ijspp.2015-0694

[13] Kartomi, M., "Traditional and modern forms of pencak silat in Indonesia: The suku mamak in Riau", Musicology Australia, 33(1), pp. 47-68, 2011. Retrieved from https://doi.org/10.1080/08145857.2011.580716

[14] T. O. Bompa, Conditioning Young Athletes. (J. Klug, Ed.), 4th ed., Stanningley, UK: Human Kinetics, 2015.

[15] Fraeger., The Weapons And Fighting Arts Of Indonesia. (D. F. Fraeger, Ed.), 1st ed., Boston, US: Tuttle Publishing, 2000.

[16] IPSI. Peraturan Pertandingan Pencak Silat. Indonesia: Ikatan Pencak Silat Indonesia, 2012.

[17] D. A. Chu, A. D. Faigenbaum, and J. E. Falkel, Progressive Plyometrics for Kids. (H. Jeanne, Ed.), Department of Health and Exercise Science (First). New Jersey, US: Healty Learning, 2006.

[18] G. Davies, Riemann, B. L., and Manske, R., "Current Concepts of Plyometric Exercise", International Journal of Sports Physical Therapy, 10 (6), 760-86, 2015. Retrieved from https://doi.org/10.1080/00754170500221345

[19] Van Lieshout, K. G., Anderson, J. G., Shelburne, K. B., and Davidson, B. S., "Intensity Rankings of Plyometric Exercises Using Joint Power Absorption", Clinical Biomechanics, 29(8), pp. 918-922, $2014 . \quad$ Retrieved https://doi.org/10.1016/j.clinbiomech.2014.06.015

[20] Rahimi, R., and Behpur, N., "The effects of Plyometric , Weight and Plyometric-Weight Training on Anaerobic Power and Muscular Strength", Facta Universitatis-Series: Physical Education and Sport, $3(1), \quad$ pp. 81-91. 2005. Retrieved from http://scindeks.nb.rs/article.aspx?artid=0354-47450501081R

[21] Zouch, M., Chaari, H., Bouajina, E., Nasr, H. Ben, Zaouali, M., and Tabka, Z., "Short-Term Lower-Body Plyometric Training Improves Whole-Body Bmc, Bone Metabolic Markers, and Physical Fitness in Early Pubertal Male Basketball Players", Pediatric Exercise Science, 26(1), pp. 22-32, 2014. Retrieved from https://doi.org/10.1123/pes.2013-0053

[22] R. Fraenkel, N. E. Wallen, and H. H. Hyun, (2012). How to Design and Evaluate Research in Education.pdf. (M. Ryan, Ed.), 8th ed., San Francisco: McGraw-Hill, 2000.

[23] A. D. Faigenbaum, J. E. McFarland, F. B. Keiper, W. Tevlin, N. A. Ratamess, J. Kang, and J. R. Hoffman, "Effects of a short-term 
plyometric and resistance training program on fitness performance in boys age 12 to 15 years", Journal of Sports Science and Medicine, 6(4), pp. 519-525, 2007.

[24] Alptekin, Kılıç, Ö., and Maviş, M., "The effect of an 8-week plyometric training program on sprint and jumping performance",
Serbian Journal of Sports Sciences, 7(2), pp. 45-50, 2013. Retrieved from

http://search.ebscohost.com/login.aspx?direct=true \&db=s3h\&AN=90 844793\&lang=es\&site=ehost-live \&scope=site 